\title{
Selenium Content, Anthelmintic, Antioxidant and Antibacterial Activities of Artocarpus Heterophyllus Lam. From Ubangi Ecoregion in Democratic Republic of the Congo
}

\author{
Koto te Nyiwa Ngbolua ${ }^{1 *}$, Emmanuel Lengbiye Moke ${ }^{1}$, Mbembo-wa-Mbembo Blaise ${ }^{1}$, Gédéon \\ Ngiala Bongo ${ }^{1}$, Paulin Mutwale Kapepula ${ }^{2}$, Nadège Kabamba Ngombe ${ }^{2}$, Marcellin Messi $^{3}$, \\ Joséphine N. Mbing ${ }^{3}$, Dieudonné Emmanuel Pegnyemb ${ }^{3}$ and Pius Tshimankinda Mpiana ${ }^{4}$
}

${ }^{1}$ Department of Biology, University of Kinshasa, Democratic Republic of the Congo

${ }^{2}$ Centre d'Etudes des Substances Naturelle's d'Origine Vegetale (CESNOV), University of Kinshasa, Democratic Republic of Congo

${ }^{3}$ Department of Organical Chemistry, University of Yaoundé I, Republic of the Cameroon

${ }^{4}$ Department of Chemistry, University of Kinshasa, Democratic Republic of the Congo

*Corresponding author: Koto Te Nyiwa Ngbolua, Department of Biology, University of Kinshasa, Kinshasa, Democratic Republic of the Congo.

To Cite This Article: Koto Te Nyiwa Ngbolua.Selenium Content, Anthelmintic, Antioxidant and Antibacterial Activities of Artocarpus Heterophyllus Lam. From Ubangi Ecoregion in Democratic Republic of the Congo. Am J Biomed Sci \& Res. 2019 - 6(2). AJBSR.MS.ID.001013. DOI: 10.34297/ AJBSR.2019.06.001013.

Received: 眥 October 03, 2019; Published: 眥 November 14, 2019

\begin{abstract}
Helminths are recognized as a one of major animal and human health problem and the gastrointestinal nematodes become resistant to currently available anthelminthic drugs; therefore, there is a foremost problem in treatment of helminths diseases. The main aim of this study was to assess the anthelminthic, antioxidant and antibacterial activities as well as the mineral content of ethanol and organic acid extracts of Artocarpus heterophyllus Lam leaves. The phytochemical profile and phenolic contents of leaves were determined by thin layer chromatography and the spectrophotometric methods. Phytochemical analysis revealed the presence of flavonoids, phenolic acids, coumarins, anthraquinones, anthocyanins, terpenoids, and the absence of alkaloids in this part of plants. Mineral composition carried out by the method of water and nitric acid and analysis by Inductively Coupled Argon Plasma Optical Emission Spectrometry (ICP-EOS) showed the abundance of different elements namely calcium, iron, potassium and selenium in this plant. Ethanolic extract and organic acid fraction exhibited dose-dependent paralysis of Benhamia rosea in the range concentrations from $0.625 \mathrm{mg} / \mathrm{mL}$ to $5 \mathrm{mg} / \mathrm{mL}$ in comparison with the standard drug Albendazole. ABTS and DPPH assays showed that these extracts can scavenge free radicals connected with their IC50 values ranging from $17.26 \pm 1.66$ to $152.1 \pm 30.20 \mathrm{mg} / \mathrm{m} \mathrm{L}$. Oleanolic acid used such as standard and organic acid fraction showed a weaker capacity to scavenge DPPH radical. Bacteriologic analysis showed that E. coli and S. aureus are not sensitive to Artocarpus heterophyllus Lam. The findings indicated that the anthelminthic and antioxidant activities of Artocarpus heterophyllus leaves support the potential therapeutic interest of this species and could justify its use in Traditional Medicine.
\end{abstract}

Keywords: Anthelmintic activity; Antioxidant activity; Antibacterial activity; Artocarpus heterophyllus; Selenium

\section{Introduction}

Over $80 \%$ of the African population relies on medicinal plants for the management of several diseases and to meet their primary healthcare [1]. In the therapy of several ailments, traditional medicine is showing a bright future and as it is performed as a good clinical practice. Plants are known to be the source of several medicines such as anthelmintic drugs. However, helminths are

recognized as one of the major problems in farms for the animal's production and constitute a public health concern as well in the tropics. Most of diseases caused by helminths are of a chronic and devastating in nature; they probably cause morbidity and greater economic and social deprivation [2]. Currently, gastrointestinal nematodes become more resistant to available anthelmintic 
drugs; this situation causes a serious problem in the treatment of helminthiases [3]. However, the chemotherapy is and remains the only treatment and effective tool to cure and control helminth infections, as effective vaccines are not yet developed until then. The random use i.e. the overuse or the misuse of synthetic anthelmintic drugs can be the cause of resistance to these drugs by the parasites. Moreover, these drugs are unaffordable due their high cost [4]. With respect to this alarming situation of resistance, a way can be paved for the use of herbal medicines as alternative anthelmintic and could help in the prevention of resistance development. In low-income countries, plants are used in ethnoveterinary and are a source of many potent and powerful drugs [5]. Artocarpus heterophyllus Lam. called jackfruit tree, is a species of tree in the Artocarpus genus (Moraceae) [6]. It has been reported that Artocarpus heterophyllus is a good diuretic and laxative remedy. In the Democratic Republic of the Congo (DRC), the leaves of jackfruit tree are used for their anthelminthic properties mainly on animals [6].

To our knowledge, few investigations reported on the chemical constituents and the biological properties of this species. The main aim of the current work was to investigate on the anthelmintic, antioxidant and antibacterial activities of ethanolic extracts and organic acid fraction.

\section{Material and Methods}

\section{Plant Material Collection}

The selection of plant species used in this study was based on previous ethnobotanical surveys [6]. The leaves of Artocarpus heterophyllus were harvested at around the University of Kinshasa, precisely at the student hostel called "Plateau des étudiants" located in Lemma municipality, Kinshasa province, DRC. This species gets identified at the Institute National d'Etudes et de Recherche's Agronomies', Department of Biology, Faculty of Sciences, University of Kinshasa. This sample was dried out in room temperature $\left( \pm 27^{\circ} \mathrm{C}\right)$ at the Molecular Bio-Prospection Laboratory, Department of Biology for two weeks and then ground to obtain fine powder for further analyses

\section{Chemicals and Reagents}

All solvents used were of analytical and HPLC grade and purchased from Merck VWR (Leuven, Belgium). Caffeic acid, Chlorogenic acid (purity: 95\%), Gallic acid (purity: 97\%) was purchased from Sigma-Aldrich. Rutin (purity $\geq 99 \%$ ), is quercitrin (purity $\geq 99 \%$ ) and, quercetin (purity $\geq 98.5 \%$ ) were HPLC grade and purchased from Extrasynthese.

\section{Preparation of Extracts}

The dried and powdered plant material $(50 \mathrm{~g})$ was repeatedly extracted with $400 \mathrm{ml}$ of ethanol (95\%) by cold percolation for 48 hours [7]. The filtrate obtained was concentrated to dryness under reduced pressure using a rotary evaporator. Organic acid fraction (triterpenic acids) was extracted as follow: the powdered stem bark of Artocarpus heterophyllus ( $40 \mathrm{~g}$ ) were macerated with 400 $\mathrm{mL}$ of dichloromethane-methanol-NH4OH (100:1:1; v/v/v) and then percolated with $300 \mathrm{~mL}$ of the same solvent mixture at room temperature. The extract was concentrated under reduced pressure until $100 \mathrm{~mL}(\mathrm{pH} 10)$. The resulting solution was then mixed with citric acid $5 \%(1: 1 ; \mathrm{v} / \mathrm{v})$ to precipitate organic/triterpenic acids. The resulting fractions were evaporated to dryness on an evaporator apparatus. All extracts were weighed and kept in dark inside hermetic flasks at $4^{\circ} \mathrm{C}$.

\section{Phytochemical Analysis}

Thin Layer Chromatographic Analysis: The phytochemical screening was performed on the aqueous and organic extracts for the identification of alkaloids, saponins, total polyphenols, flavonoids, tannins, anthocyanins, leuco-anthocyanins, quinones, terpenes and steroids following the standard protocol as described by Bruneton [8] and Tiwari et al. [9].

\section{Phenolics Contents}

Total Phenolics Content: Total phenolic content of methanolic extracts (Methanol 80\%) was determined according to the FolinCiocalteu method as described previously [7]. A calibration curve of gallic acid (0.025-0.4 mg mL1) was prepared, and phenolic contents were determined in triplicate from the linear regression equation of this curve. The results were expressed as milligrams of gallic acid (GA) equivalent per gram of dried matter.

Total Flavonoids Content: The flavonoid content of the extracts was determined by using the UV-Vis spectrophotometry method. The results are expressed in mg equivalent of quercetin per $\mathrm{g}(\mathrm{mg}$ $\mathrm{QE} / \mathrm{g}$ ) of dry vegetal material [10].

Total Anthocyanins Content: The determination of anthocyanin content of the extracts was performed in accordance with the procedure reported by Bahati et al. [10].

\section{Determination of Mineral Content}

The determination of mineral content was carried out by the method of water and nitric acid and analysis by Inductively Coupled Argon Plasma Optical Emission Spectrometry (ICP-EOS). The method with water and nitric acid, has the principle of dissolving the sample in a mixture of $5 \mathrm{~mL}$ of distilled water placed in PM60 Teflon bombs (Analytikjena 40Bar) containing 0.3g of the sample which was heated at $60^{\circ} \mathrm{C}$ and $10 \mathrm{~mL}$ of nitric acid (HNO3 65\%) (Merck) was added. The mixture was kept at the room temperature for 30 minutes in order to allow the oxidation to occur and later cover the bombs first with caps and then covers previously stripped with HNO3 / H2O (v/v, 1: 1). The bombs were placed in the high frequency microwave mineralizer (Analytikjena AG Top wave: $2.5 \mathrm{Ghz}$, Germany) controlled by microcomputer by choosing the vegetable leaves mode as a digestion mode at $180^{\circ} \mathrm{C}, 50$ bars for an hour. At the end of mixing, the digester stops by letting the 
bombs rest for 3 hours until completely cooled. The cooled analyte is thus carefully transferred by filtration on Whatman filter paper, bombs to $50 \mathrm{~mL}$ volumetric flasks previously stripped. In order to reduce the initial volume to $50 \mathrm{~mL}$ with distilled water and then place $13 \mathrm{~mL}$ of analyte in $15 \mathrm{~mL}$ conical flask previously stripped for reading by Inductively Coupled Argon Plasma Optical Emission Spectrometry (ICP-OES) [Optima 8300 Perkin Elmer, USA]. The analysis was performed in triplicate. The calibration of the ICPEOS is performed using the working standard prepared from the commercially available standard multi-element solution 3 at two points $(1 \mathrm{mg} / \mathrm{L}$ and $2.5 \mathrm{mg} / \mathrm{L}$, Perkin Elmer, USA). The most appropriate wavelength, gaseous argon flow, plasma stabilization and other ICP-EOS instrument parameters for minerals are selected and measurements are made in the linear range of the working standards used for calibration.

\section{The working conditions were:}

Instrument: ICP-EOS [Optima 8300 Perkin Elmer, USA];

Power of Rf: 1500Watt;

Plasma gas flow (Ar): 8L /min;

Nebulizer: $0.70 \mathrm{~L} / \mathrm{min}$;

Auxiliary gas flow (Ar): 0.2L / min;

Viewing size: $5-22 \mathrm{~mm}$;

Copy and playback time: $1-5$ s (maximum $45 \mathrm{~s}$ );

Flow time: 1s (maximum 10s);

View: Radial.

\section{Evaluation of Radical Scavenging Activity}

The evaluation of the antioxidant activity was performed using the ABTS and DPPH assays in accordance with Kapepula et al. protocol [10].

\section{In Vitro Anthelminthic Activity}

The in vitro anthelmintic activity of Artocarpus heterophyllus was evaluated as per the method reported by Yashaswini [11]. The tested samples prepared from the ethanol and organic acid (dichloromethane) leaf extracts were tested for their anthelminthic activity and two earthworms collected in Kinshasa city (Benhamia rosea and B. itoleisis) were used as animal model. The anthelminthic activity was evaluated on adult earthworms, Benhamia rosea due to its anatomical and physiological resemblance to the gastrointestinal nematodes. The animals were divided into 4 groups or batches of 3 worms each. The worms of group I were released into a plate containing a solution of distilled water which served as negative control. The worms of group II were released into a plate containing Albendazole in different concentrations $(5 \mathrm{mg} / \mathrm{mL}, 2.5$ $\mathrm{mg} / \mathrm{mL}, 1.25 \mathrm{mg} / \mathrm{mL}$ and $0.625 \mathrm{mg} / \mathrm{mL}$ ) which served as standard (positive control). The worms of group III and IV were released into the separate plates containing solution of samples (Organic acid fraction and ethanol extract) at different concentrations as follows $5 \mathrm{mg} / \mathrm{mL}, 2.5 \mathrm{mg} / \mathrm{mL}, 1.25 \mathrm{mg} / \mathrm{mL}$ and $0.625 \mathrm{mg} / \mathrm{mL}$ per group respectively. All the test samples were prepared in distilled water. In the study observations were made for the time taken to paralysis and death rate of individual worms. The time for paralysis was noted when no movement of any sort observed. Death was concluded when the worms lost their motility completely and failed to respond even after a touch with the needle followed by fading of their body colors. The earthworms in control group (group I) were alive up to 48 hours of the experiment. Mean values of paralysis time and death time of Benhamia rosea and Benhamia itoleisis earthworms were calculated separately.

\section{Antibacterial Activity}

The antibacterial activity of Artocarpus heterophyllus leaf extracts was performed following the micro-well dilution method on two bacteria strains namely Escherichia coli and Staphylococcus aureus. And the minimum inhibitory concentration (MIC) was obtained [7].

\section{Data Analysis}

Each concentration was tested in triplicate for each assay, and at least 3 different assays were performed. All results were expressed as mean values \pm standard deviation (SD). The statistical analysis was performed with GraphPad 7.0 (GraphPad Software, San Diego California, USA). One-way analysis (ANOVA) was used and the level of statistical significance was set at $p<0.05$. The IC50 values were calculated with GraphPad Prism 7.0 under application of the function "log (inhibitor) vs. normalized response-variable slope" after converting the concentrations into their decimal logarithm.

\section{Results and Discussion}

\section{Phytochemical Analysis}

Phytochemical analysis performed by TLC showed the presence of phenolic compounds as major compounds. These phenolic compounds are responsible of antiradical activity of plants, since this potential is strongly attributed to them [12]. By comparing with the used standards, phenolic acids such as cafeic acid and chlorogenic acid are identified in the plant $[13,14]$. These results were like those previously described that indicate the presence of flavonoids in the leaves of A. heterophyllus [15]. Figure 2 shows the presence of coumarins (blue fluorescent spots) in almost all the extracts of the tested samples. Concerning anthraquinones, Figure 2 shows the presence of anthrones (red spots) [16,17]. The presence of anthocyanins was indicated in all extracts as described in the chromatogram of figure 2. The analysis of Figure 2 shows the coloration observed in the chromatographic profiles of each sample (violet, orange) and indicates the presence of terpenes including irridoids in all extracts. These results were like those previously described by Prakash et al. and Sivagnanasundaram and 
Karunanayake [14-17] in A. heterophyllus [18] that indicated the presence of these chemical compounds in A. heterophyllus. The presence of these compounds in a plant species could confer some biological properties, such as antioxidant activity and anthelmintic activity [4]. The alkaloid test gave a negative response using Draggendorff reagent. The results of secondary metabolite assays are presented in Table 1 below.

\begin{tabular}{|c|c|}
\hline \multicolumn{2}{|c|}{ Table 1: Phenolic contents of leaves of $A$. heterophyllus. } \\
\hline Phenolic Contents & Quantities \\
\hline Total Polyphénol (Mgeag/100g) & $27.330 \pm 9.340$ \\
\hline Flavonoïde (Mgqe/100g) & $2.630 \pm 0.007$ \\
\hline Anthocyanine (Mgec/100g) & $10.460 \pm 1.050$ \\
\hline
\end{tabular}

Legend: GAE/100g Equivalent of gallic acid (GAE) per $\mathrm{g}$ of dry extract; $\mathrm{QE} / \mathrm{g}$ Equivalent of quercetin (QE) per $\mathrm{g}$ of dry extract and CE Equivalent of Cathechin

From Table 1, it is noted that A. heterophyllus is rich in phenolic compounds. The presence of polyphenol is abundant followed by the flavonoids and anthocyanins. Previous studies reported that this plant contained phenolic compounds with the flavonoids as the most abundant $[19,20]$. Studies have shown that not only extrinsic factors (such as geographic and climatic factors), genetic factors, but also the degree of maturation of the plant and the duration of storage has a strong influence on the content of polyphenols $[21,22]$.

\section{Mineral Compounds}

The mineral composition of the leaf extract of Artocarpus heterophyllus is given in the figures.

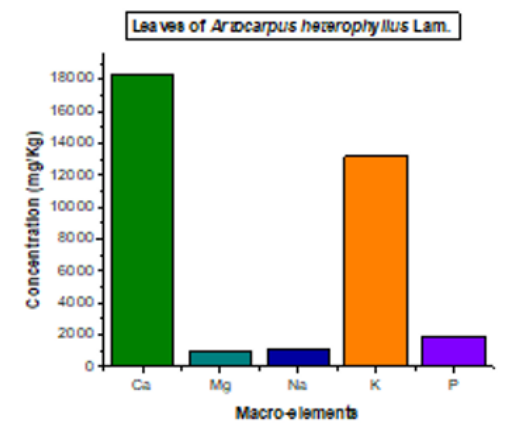

Figure 1: Concentration of Macro-Elements.

The analysis of both figures above showed that calcium is the microelement which has a remarkable predominance in terms of concentration in the leaves of this plant followed by potassium compared to other detected microelements (magnesium, sodium and phosphorus) (Figure 1). While Selenium is the microelement that has a high content followed by iron, nickel and manganese while other microelements such as Barium, Cobalt, Zinc and Copper present low concentration (Figure 2). Soetan et al. [23] reported that minerals are inorganic nutrients, usually required in small amounts from less than 1-2500 mg per day, depending on the mineral. As with vitamins and other essential food nutrients, mineral requirements vary with animal species. For example, humans and other vertebrates (like ruminants) need large amounts of calcium for construction and maintenance of bones and normal function of nerves as well as muscles. Phosphorus is an important constituent of adenosine triphosphate (ATP) and nucleic acid and is also essential for acid-base balance, bone and tooth formation.

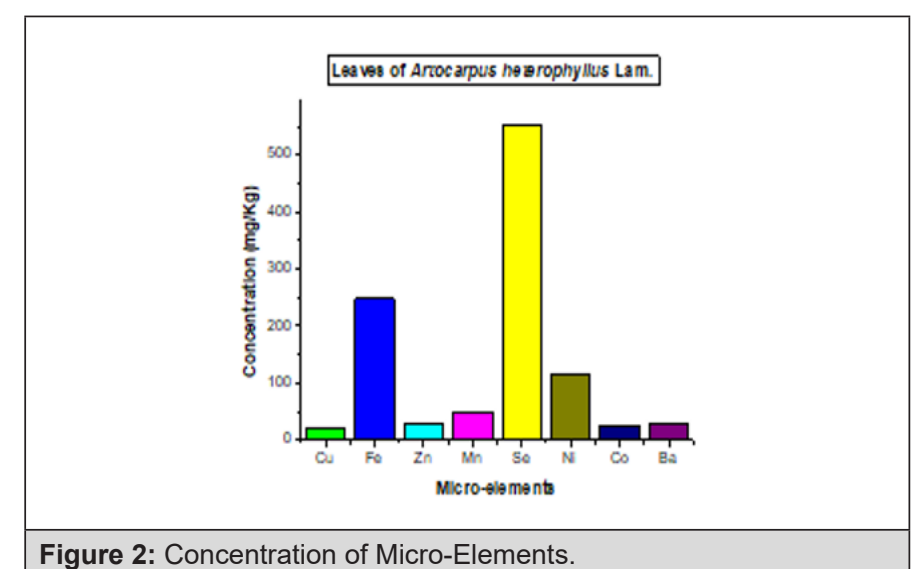

Figure 2: Concentration of Micro-Elements.

Magnesium, copper, selenium, zinc, iron, nickel and manganese are important co-factors found in the structure of certain enzymes and are indispensable in numerous biochemical pathways. Sodium and potassium are important in the maintenance of osmotic balance between cells and the interstitial fluid. Cobalt is required as a constituent of vitamin $\mathrm{B}_{12}$ and its metabolism, the same as for vitamin $\mathrm{B}_{12}$. In addition to its role in vitamin $\mathrm{B}_{12}$, cobalt is also a cofactor of enzymes involved in DNA biosynthesis and amino acid metabolism [24]. Deficiencies of cobalt in ruminants cause anorexia, wasting of skeletal muscle, fatty livers, hemosiderosis of the spleen and anaemia [23]. The interactions between nutrition and diseases, nutrition and drug metabolism have been reported. Excessive intake of some minerals can disrupt the homeostatic balance and causes toxic side effects.

\section{Antioxidant Activity}

The antioxidant activity of tested extracts determined by ABTS and DPPH assays is presented in Table 2 and is expressed as IC50 values. IC50 is the amount of antioxidant necessary to decrease the initial concentration of radical by $50 \%$. A lower IC50 value indicates a higher antioxidant activity. Oleanolic acid, organic acid fraction and ethanolic extract of A. heterophyllus showed less IC50 values inferior to $100 \mu \mathrm{g} / \mathrm{mL}$ in the ABTS test. For the DPPH test, the oleanolic acid and the organic acid fraction of A. heterophyllus seem to be inactive at tested concentrations. The capacities of various extracts to inhibit radicals vary substantially in each type of test. This difference may be due to the qualitative and/or quantitative range of secondary metabolites of the extracts. Furthermore, it should be noted that the IC50 value obtained in the ABTS test is interesting than that of the DPPH test. This difference in activity is attributed to the mechanisms of reactions. In fact, the ABTS radical 
reacts with hydrophilic and lipophilic compounds at the same time while $\mathrm{DPPH}^{\circ}$ radical reacts only with hydrophilic compounds [10]. A lower IC50 value of $A$. heterophyllus indicates a higher antioxidant activity. To our knowledge, it is for the first time that the antioxidant activity of the organic acid fraction of the leaves of A. heterophyllus is reported.

Table 2: IC50 values $(\mu \mathrm{g} / \mathrm{mL})$ of organic acid fraction of $A$. heterophyllus on ABTS and DPPH assays

\begin{tabular}{|c|c|c|}
\hline Drugs & IC50 $(\boldsymbol{\mu g} / \mathbf{m L})$ & \\
\hline & ABTS radical & DPPH radical \\
\hline Organic acid fraction & $42.85 \pm 6.35$ & $6151.80 \pm 2989.52$ \\
\hline Ethanolic extract & $17.26 \pm 1.66$ & $152.1 \pm 30.20$ \\
\hline Oleanolic acid & $42.17 \pm 1.66$ & - \\
\hline
\end{tabular}

\section{In Vitro Anthelmintic Activity}

The in vitro anthelmintic activity is depicted in Table 3 . It was found that the shorter concentration of the extract become faster due to the paralytic effect and the higher concentration of the extracts due to death rate for all earthworms. The ethanol and organic acid extracts of the plant with concentration of $5 \mathrm{mg} /$
$\mathrm{mL}, 2.5 \mathrm{mg} / \mathrm{mL}, 1.25 \mathrm{mg} / \mathrm{mL}$ and $0.625 \mathrm{mg} / \mathrm{mL}$ produced dosedepend paralysis. Ethanol extract of the leaves of A. heterophyllus showed paralysis time and death rate at $5 \mathrm{mg} / \mathrm{mL}$ in $28.00 \pm 4.20$, respectively while the organic acid extract gave paralysis and death rate in $37.00 \pm 1.40$ as compared to the standard were paralysis time and death rate was at $5 \mathrm{mg} / \mathrm{mL}$ during $18.00 \pm 2.8$ respectively. The findings displayed a hopeful prospect on anthelminthic activity of this plant, and this could be used by humans in the management of gastrointestinal nematode infection. Moreover, the findings indicated that the paralysis time taken for albendazol is near to that of the paralysis time of the ethanol extract. Phytochemical screening tests showed that the leaves of A. heterophyllus contained the phenolic compounds [6]. It was reported earlier that the tannins and phenolic were known to interfere with the energy generation in helminth parasites by uncoupling oxidative phosphorylation or they bind to the free protein of the gastrointestinal tract of the worms and led to the death while the presence of flavonoids and polyphenolic compounds were also responsible for anthelmintic activity [25]. The presence of these compounds in a plant species could confer some biological properties, such as antioxidant activity, antibacterial activity as well as the anthelmintic activity [4].

\begin{tabular}{|c|c|c|c|c|}
\hline Group & Drug Treatment & Concentration (Mg/Ml) & $\begin{array}{l}\text { Time Taken for Paralysis } \\
\text { (Min) }\end{array}$ & Death Rate (\%) \\
\hline GP-I & Distilled water & - & - & - \\
\hline \multirow{4}{*}{ GP-II } & \multirow{4}{*}{ Standard drug (Albendazol) } & 5 & $18.00 \pm 2.80$ & 33.3 \\
\hline & & 2.5 & $20.50 \pm 6.40$ & 55.6 \\
\hline & & 1.25 & $42.00 \pm 3.50$ & 66.7 \\
\hline & & 0.625 & $45.00 \pm 9.90$ & 66.7 \\
\hline \multirow{4}{*}{ GP-III } & \multirow{4}{*}{$\mathrm{OAE}$} & 5 & $37.00 \pm 1.40$ & 96.3 \\
\hline & & 2.5 & $62.3 \pm 4.80$ & 70.4 \\
\hline & & 1.25 & $44.75 \pm 3.00$ & 67 \\
\hline & & 0.625 & $76.00 \pm 2.10$ & 62.7 \\
\hline \multirow{4}{*}{ GP-IV } & \multirow{4}{*}{ EtOH } & 5 & $28.00 \pm 4.20$ & 100 \\
\hline & & 2.5 & $44.00 \pm 5.60$ & 94.4 \\
\hline & & 1.25 & $56.0 \pm 2.80$ & 66.7 \\
\hline & & 0.625 & $67.30 \pm 1.80$ & 33.3 \\
\hline
\end{tabular}

Legend: OAE: organic acid extract; EtOH: ethanolic extract; GP: group

These results were like those previously described by Shekhunat and Vijayvergia [26] and Yashaswini et al. [11] who reported a higher anthelminthic activity with ethanol extract of the seeds of A. heterophyllus Lam. It was reported in the literature that the anthelminthic drugs having the imidazothiazole core as Albendazole have the property to be fixed on the nicotinic receivers at acetylcholine of the parasitic worms as thus mimics the action of acetylcholine. This fixing induces the permeability change of the post-synaptic membrane causing a muscular contraction, followed by the spastic paralysis and finally, the death of the worms [27]. On the contrary, the polyphenols like tannins would have the capacity to bind to proteins and, consequently would modify the physical properties and biochemical parasitic worms. Indeed, they would interact with the worms while being fixed at the macromolecules of the cuticule or of the sheath of the L3s larvae (containing proteins rich in proline and hydroxyproline) or would fix them to the secrete enzymes over the worms and would block their activity [28]. It was considered that the interactions between tannins and proteins of 
the exoskeleton (the cuticule), the alimentary canal even the genital structures of the worms would affect some essential functions like the nutrition or reproduction [29].

\section{Antibacterial Activity}

The antibacterial avtivty of the leaves of A. heterophyllus is presented in the Table 4 . The results of antibacterial activity showed E. coli and S. aureus are not sensitive to A. heterophyllus with the CMIs $>1000 \mu \mathrm{g} / \mathrm{mL}$ ) This antibacterial activity is however weak (MIC $>1000 \mu \mathrm{g} / \mathrm{mL}$ ) [30] and would be due to the presence of phenolic and triterpenic compounds present in the tested extracts. The bioactivity would be due to the nature of their wall [31]. Indeed, S. aureus is a positive gram bacterium. Its wall is thick (several layers) and would be the pharmacological target of the biologically active compounds present in A. heterophyllus leaves. These results corroborate with studies on the antimicrobial properties of the secondary metabolites of plant origin $[32,33]$.

\begin{tabular}{|c|c|c|}
\hline \multicolumn{3}{|c|}{ Table 4: Antibacterial effect of plant extracts } \\
\hline Microorganisms (Gram) & \multicolumn{2}{|c|}{ Samples Concentrations ( $\mathbf{\mu g}$ / } \\
\hline & OAE & EtOH \\
\hline & 1000 & 1000 \\
\hline Escherichia coli ATCC 27195 (-) & MIC & MIC \\
\hline $\begin{array}{c}\text { Staphylococcus aureus ATCC } \\
\text { 25923 (+) }\end{array}$ & MIC & MIC \\
\hline
\end{tabular}

Légend: OAE: organic acid extract; $\mathrm{EtOH}$ : ethanol extract; +: gram positive; -: gram negative

\section{Conclusion}

The present study evaluated the chemical composition, minerals compound, the anthelminthic, antioxidant and antibacterial activities of the leaf extracts of A. heterophylly. The findings revealed that the leaves of $A$. heterophyllus contained various secondary metabolites such as the anthocyanins, coumarins, anthraquinones, flavonoids, phenolic acids and terpenoids. The leaves of A. heterophyllus contained also various minerals such as calcium and selenium. Organic acid extract revealed an interesting antioxidant activity. The ethanol and organic acid extracts exhibited significant anthelminthic activity. The antibacterial activity of the plant extracts was weak toward tested bacterial strains. The tested samples can be evaluated further for other pharmacological properties, which may be useful in the design of new anthelmintic drugs.

\section{Acknowledgment}

The authors express their gratfull to "Agence Universitaire de la Francophonie (AUF) for Grant N ${ }^{\circ}$ DRACGL-2017-007. They thank the Laboratory of Systematic, Management of Natural Resource, Faculty of Agronomy Science, University of Kinshasa and Professor Millau Empwal for their technical supports.

\section{Conflict of Interest}

Author has no conflict of interest.

\section{References}

1. Ngbolua KN, Rafatro H, Rakotoarimanana H, Urverg RS, Mudogo V, et al. (2011) Pharmacological screening of some traditionally used antimalarial plants from the Democratic Republic of Congo compared to its ecological taxonomic equivalence in Madagascar. Int J Biol Chem Sci 5(5): 1797-1804.

2. Pratap S, Kumar S, Kumar A, Sharma NK, Jha KK (2012) In vitro anthelmintic activity of Luffa cylindrica leaves in Indian adult earthworm. J Pharmacologn Phytochem 1(2): 20.

3. Qureshi SMd, Patel J, Giri CI, Hasan S, Shaik M, et al. (2010) In vitro anthelmintic activity of root extract of Trapabispiniosa Roxb. Against Pheretimaposthuma and Ascardiagilli. Study of anthelmintic activity. International Journal of Pharma Science and Research 1(9): 353-356.

4. Coles GC, Jackson F, Pomroy WE, Prichard RK, Von samson-Himmelstjerna G, et al (2006) The detection of anthelmintic resistance in nematodes of veterinary importance. Vet. Parasitol 136(3-4): 167-185.

5. Pessoa LM, Morias SM, Bevilaqua CM Luciano JH (2002) Anthelmintic activity of essential oil of Ocimum gratissimum Linn.And euginol against Haemonchus contortus. Vet Parasitol 109(1-2): 59-63.

6. Lengbiye EM, Koto te Nyiwa N, Gédéon NB, Lin MM, 0 l i v i e $r$ PN, et al. (2018) Artocarpus heterophyllus Lam. (Moraceae): Phytochemistry, Pharmacology and Future Directions, a mini review. J of Advanced Botany and Zoology 5(3): 2348-7313.

7. Damien STT, Ngbolua KN, Lengbiye EM, Dorothée DT, Bienvenu MM, et al. (2016) Chemical composition and bioactivity of Canarium schweinfurthii stem bark extracts from DR Congo against Sickle cell disease and associated bacteria. Journal of Pharmacognosy and Phytochemistry 5(4): 181-187.

8. Bruneton J (1999) Pharmacognosie, Phytochimie et Plantes médicinales. Edition Technique et Documentation-Lavoisier, 3ème edition, Paris 421499.

9. Tiwari P, Kumar B, Kaur M, Kaur G, Kaur H (2011) Phytochemical Screening and Extraction: A review. Int Pharmac Scienc 1(1): 98-106.

10. Kapepula PM, Mungitshi PM, Franck T, Mouithys Mickalad A, Ngoyi DM, et al. (2016) Antioxidant potentiality of three herbal teas consumed in Bandundu rural areas of Congo. Nat Prod Res 31(16): 1940-1943.

11. Yashaswini T, Akshara KAM, Prasad K, Kumar MD, Akshaykumar K (2016) Anthelmintic activity of seed extracts of Artocarpus heterophyllus. IOSR Journal of Pharmacy and Biological Sciences 11(5): 19-23.

12. Gédéon B, Inkoto C, Colette M, Claudine T, Lengbiye EM, et al. (2017) Assessment of Antisickling, Antioxidant and Antibacterial Activities of Some Congolese Taxa: Aframomum alboviolaceum (Ridley) K. Schum, Annona senegalensis Pers. and Mondia Whitei (Hook. f.) Skeels. American Journal of Laboratory Medicine 2(4): 52-59.

13. Chandrika UG, Jansz ER, Warnasuriya ND (2004) Analysis of carotenoids in ripe jackfruit (Artocarpus heterophyllus) kernel and study of their bioconversion in rats. J Sci Food Agric 85(2): 186-190.

14. Prakash O, Srivastava R, Kumar R, Mishra S, Srivastava S (2015) Preliminary Pharmacogenetic and Phytochemical Studies on leaves of Artocarpus heterophyllus. International journal of natural products and marine biology (1): 35- 40.

15. Saxena K, Irchhaiya R, Khushboo, Chagti KK (2016) Antihepatotoxic Effect of Artocarpus heterophyllus Leaves against Paracetamol induced Hepatic Damage in Albino rats. International journal of pharmacy \& life sciences 7(2): 4895- 4899.

16. Thapa N, Thapa P, Bhandari J, Niraula P, Shrestha Net, et al. (2016) Study of Phytochemical, Antioxidant and Antimicrobial Activity of Artocarpus heterophyllus. Nepal Journal of Biotechnology 4 (1): 47-53.

17. Sivagnanasundaram, Karunanayake KOLC (2015) Phytochemical Screening and Antimicrobial Activity of Artocarpus heterophyllus and Artocarpus altilis Leaf and Stem Bark Extracts. OUSL Journal (9): 1- 17. 
18. Manjeshwar SB, Arnadi RS, Jerome D, Harshith PB. (2011) Phytochemistry, nutritional and pharmacological properties of Artocarpus heterophyllus Lam (jackfruit): A review. Food Research International 44(7): 18001811.

19. Umesh BJ, Shrimant NP and Bapat VA (2010) Evaluation of antioxidant capacity and phenol content in jackfruit (Artocarpus heterophyllus Lam.) fruit pulp. Plant Foods Hum Nutr 65(2): 99-104.

20. Sreelatha AS, Lini JJ, Dhanya lakshmi CS, Sabu KR, Pratap CR (2017) Phytochemical, Proximate, Antimicrobial, Antioxidant and FTIR Analyses of Seeds of Artocarpus heterophyllus Lam 5(1): 41-50.

21. Salma A (2015) L'effet des facteurs climatiques sur la variation de queleas métabolites secondaries sieves de l'activité antibactérienne chez les deux espèces Hyoscyamus albus L. et Hyoscyamus muticus L. Mémoire de mastère, Universities des Frères Mentouri Constantine Faculty des Sciences de la Nature et de la Vie. Algerie pp.112.

22. Dao VT (2008) Effects de Environment sur la croissance et accumulation des métabolites secondaries de Datura innoxia Mill. Cultivé an conditions hors sol impacts des facteurs biotiques et abiotiques. These, Doctorate en Sciences Agronomiques Institute national polytechnique de Lorraine Ecole national supérieure d'agronomie et des industries alimentaires; pp238.

23. Soetan KO, Olaiya CO, Oyewole OE (2010) The importance of minera elements for humans, domestic animals and plants: A review. African Journal of Food Science; 4(5) pp. 200-222.

24. Arinola OG, Nwozo SO, Ajiboye JA, Oniye AH (2008) Evaluation of trace elements and total antioxidant status in Nigerian cassava processors Pak, Nutr7(6): 770-772.

25. Panda SK, Das D and Tripathy NK (2011) Evaluation of anthelmintic activity of Chlorophytum borivilianum santapau \& fernandes. Int J Res Pharm Biomed Sci; 21: 571-576.

26. Vidyadhar S, Saidulu M, Gopal TK, Chamundeeswari D, Umamaheswara $\mathrm{R}$, et al. (2010) In vitro anthelmintic activity of the whole plant of
Episteme littorale by using various extracts. International Journal of Applied Biology and Pharmaceutical Technology; 1(3): 1119-1125.

27. Zouiten H (2006) Résistance aux anthelminthiques des nématodes parasites du tube digestif chez les ovins et les équidés au Maroc. Thèse doctorat $\mathrm{N}^{\circ} 2312$. Université Mohammed v- Agdal Faculty des sciences Rabat. (141): 8-19.

28. Min BR, Barry TN, Attwood GT, Mc Nabb WC (2003) The effect of condensedtannins on the nutrition and health of ruminants fed fresh temperate forages: a review. Anim. Feed Sci. Technol. 106(1-4): 3-19.

29. Molan AL, Sivakumaran S, Spencer PA and Meagher LP (2004). Green tea flavan-3-ols and oligomeric proanthocyanidins inhibit the motility of infective larvae of Teladorsagia circumcincta and Trichostrongylus colubriformis in vitro. Res. Vet. Sci. 77(3): 239-243.

30. Ngbolua KN, Tshibangu DST, Mpiana PT, Shetonde OM, Mavakala BK, et al. (2015) Anti-sickling and antibacterial activities of Some Extracts from Gardenia ternifolia subsp. jovis-tonantis (Welw) Verdc (Rubiaceae) and Uapaca heudelotii Baill (Phyllanthaceae); Journal of Advances in Medical and Pharmaceutical Sciences 2(1): 10-19.

31. Ngbolua KN, Mubindukila NR, Mpiana PT, Tshibangu DST, Masengo CA et al (2014) Phytochemical screening, Antibacterial and Antioxidant activities of Anthocleista liebrechtsiana Wild \& T Durand (Gentianaceae) originated from Democratic Republic of the Congo. Journal of Advancement in Medical and Life Sciences 1(3): 13.

32. Ngbolua KN, Mubindukila NR, Mpiana PT, Masengo CA, Baholy R, et al. (2014) In vitro Assessment of Antibacterial and Antioxidant activities of a Congolese medicinal plant species Anthocleista schweinfurthii Gilg (Gentianaceae). J of Modern Drug Discovery and Drug Delivery Research; pp. $1 \mathrm{I} 3$.

33. Tshilanda DD, Onyamboko DNV, Babady PB, Ngbolua KN, Tshibangu DST, et al. (2015) Anti-sickling Activity of Ursolic Acid Isolated from the Leaves of Ocimum gratissimum L. (Lamiaceae). Natural Products and Bioprospecting 5(4): 215-221. 